\title{
The RAS Effector RIN1 Modulates the Formation of Aversive Memories
}

\author{
Ajay Dhaka, Rui M. Costa, ${ }^{2}$ Hailiang Hu, ${ }^{1}$ Dwain K. Irvin, ${ }^{3}$ Apoor Patel, ${ }^{1}$ Harley I. Kornblum, ${ }^{3}$ Alcino J. Silva, ${ }^{2}$ \\ Thomas J. 0'Dell, ${ }^{4}$ and John Colicelli ${ }^{1}$ \\ Departments of ${ }^{1}$ Biological Chemistry, ${ }^{2}$ Neurobiology, ${ }^{3}$ Molecular and Medical Pharmacology, and ${ }^{4}$ Physiology, and Molecular Biology Institute, University \\ of California, Los Angeles School of Medicine, Los Angeles, California 90095-1737
}

\begin{abstract}
RAS proteins are critical regulators of mitosis and are mutationally activated in many human tumors. RAS signaling is also known to mediate long-term potentiation (LTP) and long-term memory formation in postmitotic neurons, in part through activation of the RAF-MEK-ERK pathway. The RAS effector RIN1 appears to function through competitive inhibition of RAS-RAF binding and also through diversion of RAS signaling to alternate pathways. We show that RIN1 is preferentially expressed in postnatal forebrain neurons in which it is localized in dendrites and physically associated with RAS, suggesting a role in RAS-mediated postsynaptic neuronal plasticity. Mice with an Rin1 gene disruption showed a striking enhancement in amygdala LTP. In addition, two independent behavioral tests demonstrated elevated amygdala-dependent aversive memory in $R i n 1^{-1-}$ mice. These results indicate that RIN1 serves as an inhibitory modulator of neuronal plasticity in aversive memory formation.
\end{abstract}

Key words: RIN1; RAS; ABL; amygdala; aversive memory; hippocampus; LTP; dendrites

\section{Introduction}

Activated RAS proteins (HRAS, KRAS, and NRAS) dispatch signals directly to downstream effectors, including RAF proteins (proximal kinases in a MAP kinase cascade, including MEK and ERK proteins), PI3K, RalGDS, NORE1, and RIN1. The outcome of RAS signaling is determined by the cell type expression pattern and distinct biochemical properties of these effectors.

RAS was first associated with mitosis and neoplastic transformation. However, a learning and memory function for RAS is supported by results from experiments examining behavior and long-term potentiation (LTP), a physiological correlate of the synaptic plasticity thought to be required for memory formation (Bliss and Collingridge, 1993). First, mutations of brainexpressed RAS regulators can result in learning deficits. A null mutation of GRF1, a brain enriched RAS-GEF (RAS activator), led to amygdala-specific deficits in memory and LTP (Brambilla et al., 1997) and to some perturbations of hippocampusdependent behavior (Giese et al., 2001). A mutation in NF1, a RAS-GAP (RAS inhibitor), also results in learning disabilities (Ozonoff, 1999), and mice with Nf1 mutations have spatial memory deficits (Silva et al., 1997; Costa et al., 2001). A null mutation in SynGAP, a postsynaptic density (PSD) enriched RAS-GAP, also disrupts LTP (Komiyama et al., 2002). Second, blockade of

\footnotetext{
Received Sept. 6, 2002; revised 0ct. 25, 2002; accepted 0ct. 30, 2002.

This work was supported by National Institutes of Health (NIH) Grant CA56301 (J.C.), NIH Grant MH60919 and the Pew Charitable Trust (T.J.0.), United States Department of Energy Contract DE-FC03-ER60615 (H.I.K.), the Graduated Program in Basic and Applied Biology of the University of Oporto (R.M.C.), the Portuguese Foundation for Science and Technology and the National Neurofibromatosis Foundation (NNF), and NIH, Neurofibromatosis Inc. (National, Illinois, Massachusetts Bay Area, Minnesota, Arizona, Kansas and Central Plains, Mid-Atlantic, and Texas chapters), the Merck Foundation, the NNF Foundation, and a generous donation from K. M. Spivak (A.J.S.). We thank Harry Vinters and Justine Garakian for providing human brain tissue and technical advise. We thank the following for technical advise and critical comments: Hong Wu, Karen Lyons, Michael Fanselow, Matt Sanders, Paul Frankland, and Sheena Josselyn.

Correspondence should be addressed to John Colicelli at the above address. E-mail: colicelli@mednet.ucla.edu. Copyright $\odot 2003$ Society for Neuroscience $\quad 0270-6474 / 03 / 230748-10 \$ 15.00 / 0$
}

RAS effector pathways disrupts learning and memory. Inhibitors of phosphatidylinositol 3 kinase disrupt amygdala-dependent learning and LTP (Lin et al., 2001), whereas inhibitors of MEK suppress LTP and disrupt learning (English and Sweatt, 1997; Atkins et al., 1998; Blum et al., 1999; Schafe et al., 2000), presumably attributable to a reduction in ERK activation (English and Sweatt, 1996). Consistent with this, changes in dendritic morphology appear to be dependent on RAS-RAF-MEK-ERK signaling (Wu et al., 2001). Finally, K-RAS-dependent ERK activation is necessary for normal LTP and learning (Ohno et al., 2001).

RIN1 is a RAS effector that binds with specificity and high affinity to activated RAS (Han et al., 1997; Wang et al., 2002). RIN1 and RAF1 directly compete for RAS binding in vitro, and overexpressed RIN1 inhibits RAS-RAF signaling as judged by assays of ERK protein activation in PC12 cells (A. Dhaka and J. Colicelli, unpublished data) or by fibroblast transformation assays (Wang et al., 2002). RIN1 signaling is at least in part mediated by ABL family tyrosine kinases. The $\mathrm{N}$-terminal domain of RIN1 binds to ABL1 (also known as c-Abl) and enhances transformation by BCR-ABL. RIN1 also binds to and stimulates the activity of ABL2 (also known as Arg) (H. Hu and J. Colicelli, unpublished data). In addition, RIN1 has guanine nucleotide exchange factor activity for RAB5, a G-protein involved in recycling of cell surface receptors (Tall et al., 2001). These observations suggest that endogenous RIN1 can divert signaling away from RAF and the MAPK pathway while at the same time shunting RAS signals through alternate pathways.

Whether RAS signaling flows through RAF or RIN1 should depend on relative availability. RAF proteins (RAF1, ARAF, and BRAF) are expressed ubiquitously, albeit with distinct patterns for isoforms and splice variants. In contrast, we report that RIN1 is localized predominantly in the cell bodies and dendrites of postnatal neurons of the forebrain. Rin 1 null mice showed elevated amygdala LTP and concomitant en- 
hancement of associative amygdala-dependent aversive memory. In contrast, hippocampal-dependent LTP and learning appeared normal in the mutant mice. We also show that a portion of RAS is physically engaged with RIN1 in normal brain. These results establish that RIN1 is a critical modulator of neuronal plasticity and memory formation in the amygdala, a region that controls emotion processing.

\section{Materials and Methods}

Generation of Rin $1^{-/-}$mice. A mouse $129 /$ SvJ genomic library in Lambda FIX II vector (Stratagene, La Jolla, CA) was screened with a rat Rin1 cDNA probe. A $6 \mathrm{~kb}$ BglII fragment, spanning from intron 1 to $2.2 \mathrm{~kb}$ beyond exon 10, was cloned into Bluescript SK II (Stratagene) (M99$1 \mathrm{Bgl} \mathrm{II})$. Subsequently, a $6 \mathrm{~kb} B a m \mathrm{HI}-E c o$ RI fragment, covering from 4 $\mathrm{kb}$ upstream of the Rin 1 start codon to intron 6, was isolated and cloned into Bluescript SK II (M99RB). The targeting vector was created in a two-step process, in which a $3 \mathrm{~kb}$ section from exon 2 through exon 7 of Rin1 was deleted. First, M99RB was digested with BglII and EcoRI, and a $2 \mathrm{~kb}$ PGK-driven neomycin resistance cassette [pGEM7 (KJ1) SalI digested with $B g l \mathrm{II}$ and $E c o \mathrm{RI}$ ] was ligated in the opposite transcriptional orientation (M99RBNeo). Second, M99RBNeo was digested with EcoRI and HindIII and ligated to an XbaI-HindIII fragment from M99-1Bgl II containing exons $8-10$ of Rin1, using EcoRI-XbaI linkers 5'AATTGCAT- $3^{\prime}$ and $5^{\prime}$-CTAGATGC- ${ }^{\prime}$. The resulting $8 \mathrm{~kb}$ targeting vector contained $4 \mathrm{~kb}$ of sequence upstream and $2 \mathrm{~kb}$ of sequence downstream of the neomycin cassette. GS1 embryonic stem cells (Genome Systems, St. Louis, MO) were grown and electroporated with NotI-Hind III linearized targeting vector. Two hundred neomycin-resistant colonies were picked and expanded, and genomic DNA was isolated. Gene disruptions were identified by Southern blot analysis with $5^{\prime}$ and $3^{\prime}$ probes, and a normal karyotype was confirmed. Chimeric mice were generated, and the males were mated to $\mathrm{C} 57 \mathrm{BL} / 6$ or $\mathrm{BALB} / \mathrm{cj}$ females to obtain $\mathrm{F} 1$ mice heterozygous for the Rin 1 mutation. The genotypes of animals were determined by Southern blot as described above or by PCR using $3^{\prime}$ oligonucleotide primers: exon 7, 5'-GTCATCTAGAGCAGAATTGGTCCTGGAGAA-3'; intron 7, 5' -ACAGGGCACAAAGGCACTATTC3'; and pGEM7 (KJ1), 5' -TATTGGCCGCTGCCCCAAAG-3'. F1 +/mice were intercrossed to generate $129 / \mathrm{SvJ} \times \mathrm{C} 57 \mathrm{BL} / 6$ or $129 / \mathrm{SvJ} \times$ BALB/cj F2 hybrids. F2 129/SvJ $\times$ C57BL/6 +/+ and - /- littermates were used in all behavior, electrophysiology, physiology, and expression experiments, except for Northern blot analysis, for which F2 129/SvJ $\times$ $\mathrm{BALB} / \mathrm{cj}$ animals were used. All experiments were performed blind with respect to genotype and were conducted with the approval of the University of California, Los Angeles, Animal Research Committee.

Pathology. For the purposes of postmortem examination, age- and sex-matched adults were culled by $\mathrm{CO}_{2}$ asphyxiation. After gross examination, tissues were immersion fixed overnight in $4 \%$ Formalin. The maximum time between death and tissue fixation was $10 \mathrm{~min}$. After fixation, tissues were processed and embedded in paraffin, and $4 \mu \mathrm{m}$ sections were cut and stained with hematoxylin and eosin. Forty to 50 levels from the brain of each mouse were examined. Selected brain sections from each mouse containing the amygdaloid nuclei were stained with Kluver-Barrera stain.

Northern blot. Total brain RNA was extracted using TRIzol reagent (Invitrogen, Gaithersburg, MD) according to the instructions of the manufacturer. Total RNA (30 $\mu \mathrm{g})$ from each brain was denatured, subjected to gel electrophoresis, and transferred to Hybond-N+ (Amersham Biosciences, Arlington Heights, IL) membranes. A Rin1 probe was generated by PCR (exon 7 primers, 5'-GTCATCTAGAGCAGAATTGGTCCTGGAGAA and 5'-GTCACTCGAGTTCAGGGCTGTGTATAGCA). The resulting fragment was digested with $\mathrm{XbaI}$ and $\mathrm{XhoI}$ and cloned into Bluescript SK II (E7 SK) or Bluescript KS II (E7 KS). Rin1 and glyceraldehyde-3-phosphate dehydrogenase (Gapdh) (Ambion, Austin, TX) probes were hybridized to filters in ExpressHyb (Clontech, Cambridge, UK) and washed according to the instructions of the manufacturer and developed by a PhosphorImager (Molecular Dynamics, Sunnyvale, CA).
Biochemistry. Mouse hippocampus samples were lysed in $100 \mu \mathrm{l}$ of boiling lysis buffer (50 mм Tris-HCl, pH 6.8, 200 mм DTT, 2\% SDS, 10\% glycerol, $1 \mathrm{~mm}$ PMSF, $1 \mathrm{~mm}$ sodium orthovanadate, 5 mm sodium pyrophosphate, and protease inhibitor cocktail) for $10 \mathrm{~min}$ and then cleared by centrifugation for $15 \mathrm{~min}$ at $16,000 \times g$ at $4^{\circ} \mathrm{C}$. Human brain was homogenized in a hypotonic solution using a polytron, centrifuged to collect cytoplasmic material, and fractionated over a sucrose gradient as described previously (Wang et al., 2002) to separate plasma membrane material from microsomal material. Protein concentration was determined by Bradford analysis (Bio-Rad, Hercules, CA). Samples containing equivalent amounts of protein $(60 \mu \mathrm{g})$ were separated on a $10 \%$ SDS-PAGE gel for $1 \mathrm{hr}$ at $200 \mathrm{~V}$ and transferred overnight onto a Hybond ECL nitrocellulose membrane (Amersham Biosciences). The membrane was blocked with $5 \%$ dry milk in TBS-T (TBS with $0.1 \%$ Tween 20 ) for 1 $\mathrm{hr}$ and then incubated with anti-RIN1 (human) or anti-Rin1 (mouse) (1 $\mu \mathrm{g} / \mathrm{ml}$, Protein A bead purified) for $1 \mathrm{hr}$. The membrane was washed three times with TBS-T for $5 \mathrm{~min}$ and incubated for $1 \mathrm{hr}$ with a horseradish peroxidase-conjugated secondary antibody. Protein signals were then detected using ECL (Amersham Biosciences). Immunoprecipitations were performed using $800 \mu \mathrm{g}$ of total protein from wild-type (WT) or mutant mouse forebrain lysates prepared in radioimmunoprecipitation assay buffer. This was incubated overnight at $4^{\circ} \mathrm{C}$ with $30 \mu \mathrm{l}$ of agarose bead-conjugated anti-RAS(238) (Santa Cruz Biotechnology, Santa Cruz, CA), anti-MYC (Clontech), or anti-Flag (Sigma, St. Louis, $\mathrm{MO}$ ). The beads were washed four times with TBS-T and boiled in protein sample buffer. Immunoblot analysis was performed using antiRin1 (mouse) or anti-RAS (BD Biosciences). Purified Rin1 $\left(\mathrm{His}_{6}\right.$ ) was used as antigen to produce polyclonal (rabbit) anti-Rin1 (QCB, Camarillo, CA). Rin1 cDNA was amplified from a mouse brain library (Clontech). Oligonucleotides (5'-TATCGAATTCCATGGAGAGCTCAGTGGGATTATC and 5'-AGTCGGATCCCTCTTCCAAAGCCTGGCTT) were used to permit inframe cloning of amplified product into pQE60 (Qiagen, Hilden, Germany), and $\operatorname{Rin} 1\left(\mathrm{His}_{6}\right)$ protein was subsequently purified on a Talon affinity resin column (Clontech).

In situ hybridization. In situ hybridization was performed as described previously (Irvin et al., 2001). Brains or whole embryonic heads, from C57BL/6 mice (The Jackson Laboratory, Bar Harbor, ME), were frozen in 2-methylbutane, and $20 \mu \mathrm{m}$ sections were cut on a cryostat. Sections were fixed in $4 \%$ paraformaldehyde, rinsed, dried, and stored at $-80^{\circ} \mathrm{C}$. Sections were later thawed, rinsed, dipped in acetic anhydride, and dehydrated-defatted in graded ethanol and chloroform. For hybridization, $1 \times 10^{7} \mathrm{cpm} / \mathrm{ml}\left[{ }^{35} \mathrm{~S}\right]$-labeled riboprobes in a non-aqueous solution were used. E7 SK (antisense) and E7 KS (sense) were linearized, and riboprobes were transcribed in the presence of $\left[{ }^{35} \mathrm{~S}\right] \mathrm{UTP}$ (NEN, Boston, MA). Sections were rinsed and treated with RNase A (Sigma), rinsed again, and washed with multiple high-stringency rinses. The sections were then dried and exposed to film (Amersham $\beta$ Max) for 3-7 d. Subsequently, sections were dipped in NTB2 emulsion (Eastman Kodak, Rochester, NY) and counterstained with cresyl violet.

Immunohistochemistry. Paraffin-embedded human surgical brain sections $(4 \mu \mathrm{m})$ (provided by University of California, Los Angeles, Alzheimer Disease Research Center Neuropathology Core) or $4 \mu \mathrm{m}$ paraffinembedded mouse sections were processed by standard methods. Sections were deparaffinized, rehydrated, and incubated for $45 \mathrm{~min}$ in $0.1 \mathrm{M}$ sodium citrate at $120^{\circ} \mathrm{C}$ to unmask antigenic sites. The sections were blocked in 5\% normal goat serum and 5\% bovine serum albumin and incubated in polyclonal RIN1 (human) antibody (1:200) (Transduction Laboratories, Lexington, KY) or polyclonal Rin1 (mouse) antibody (1: 3000 ), overnight at $4^{\circ} \mathrm{C}$. Primary antibody was detected using the Vector rabbit $\mathrm{ABC}$ elite peroxidase kit (Vector Laboratories, Burlingame, $\mathrm{CA}$ ) and visualized with diaminobenzidine. Sections were counterstained with hematoxylin (Biomedia).

Water maze. Water maze experiments were performed as described previously (Bourtchuladze et al., 1994). Briefly, the circular pool has a diameter of $1.2 \mathrm{~m}$, and the platform has an $11 \mathrm{~cm}$ diameter. Pool water was made opaque with white paint and warmed to $27^{\circ} \mathrm{C}$. Movement of mice was recorded with the VP118 digital tracking device (HVS Image, Buckingham, UK). During the hidden platform test, the platform was submerged $\sim 1 \mathrm{~cm}$ below the surface of the water and kept in the same 
position throughout training. Starting position was varied between trials. In all training and trials, mice were given a maximum of $60 \mathrm{sec}$ to find the platform. Mice were given two training trials per day [30 sec intertrial interval (ITI)] from varied starting points. On days 8,10 , and 12 , a probe trial was performed after training and a platform cue (animal placed on platform for $5 \mathrm{sec}$ immediately before placement in the pool). For the long-term memory assessment protocol, mice received four training trials per day, but probe trials were performed $24 \mathrm{hr}$ after training and without a platform cue.

Fear conditioning. Fear conditioning experiments were performed as described previously (Anagnostaras et al., 2000). Mice were placed in the conditioning chamber (chamber A). After $2 \mathrm{~min}$, a $30 \mathrm{sec}, 90 \mathrm{~dB}$ tone (A-scale), which coterminated with a $2 \mathrm{sec}$ foot shock $(0.5$ or $0.75 \mathrm{~mA})$, was given. The mice were returned to their home cages $150 \mathrm{sec}$ later. Forty-eight hours after training, the mice were placed in a novel chamber (chamber B) and tested for freezing to the tone. After a 2 min baseline, the original training tone was played for $3 \mathrm{~min}$. A separate group of animals was tested $30 \mathrm{~min}$ after training (chamber A) for freezing to the tone (chamber B). Freezing activity and shock reactivity were scored by computerized measurements using NIH Image.

Conditioned taste aversion. Experiments were performed as described previously (Ferguson et al., 2000). Mice were weighed and water deprived for $20 \mathrm{hr}$, moved to individual cages with ab libitum access to water from two bottles for $40 \mathrm{~min}$, and then returned to home cages. On day 2, the mice were given access to water for $40 \mathrm{~min}$. On days $3-5$, water access was limited to $20 \mathrm{~min}$. The mice were weighed every day. Weight loss $>20 \%$ was a disqualifying criterion (no mice were excluded). On day 6 , mice were given access for $20 \mathrm{~min}$ to a single bottle with a $0.2 \%$ saccharin solution. Forty minutes later, mice were injected ( $2 \%$ of body weight) with PBS or $0.3 \mathrm{M} \mathrm{LiCl}$ and then returned to home cages. To prevent dehydration, mice were given $20 \mathrm{~min}$ access to water $2 \mathrm{hr}$ after injection. The following day, mice were presented with the saccharin-flavored water and plain water in separate bottles (bottle positions counterbalanced across cages). To determine consumption, bottles were weighed before and after testing. Conditioned taste aversion (CTA) was calculated as follows: (saccharin water consumed/(saccharin water consumed + normal water consumed)).

Rotarod. Mice were placed on a rotarod (model 7850; Ugo Basile, Comerio, Italy), which accelerated from 4 to $40 \mathrm{rpm}$ in $300 \mathrm{sec}$. Five trials (30 min ITI) were performed. If animals fell off during the first $10 \mathrm{sec}$, they were retested. The latency to fall was measured. Any mouse that grabbed the rotarod with all four paws to avoid falling was scored as a fall.

Open field. Open field analysis was performed as described previously (Silva et al., 1997). Mice were observed in a white circular arena $(60 \mathrm{~cm}$ in diameter). The animals were placed in the center of the arena, and movements were tracked for 5 min using the HVS Image VP118 tracking system.

Electrophysiology. Hippocampal and amygdala slices (400 $\mu \mathrm{m}$ thick) were prepared using standard techniques and maintained in an interface recording chamber perfused with warmed $\left(30^{\circ} \mathrm{C}\right)$, oxygenated $(95 \%$ $\mathrm{O}_{2}-5 \% \mathrm{CO}_{2}$ ) artificial CSF (ACSF) containing the following (in $\mathrm{mm}$ ): $124 \mathrm{NaCl}, 4.4 \mathrm{KCl}, 25 \mathrm{NaHCO}_{3}, 1.0 \mathrm{NaH}_{2} \mathrm{PO}_{4}, 1.2 \mathrm{MgSO}_{4}, 2.0 \mathrm{CaCl}_{2}$, and 10 glucose. Extracellular recordings were performed using lowresistance (5-10 M $\Omega$ ) glass microelectrodes filled with ACSF. Bipolar stimulating electrodes fabricated from Formvar-insulated nichrome wire were use to activate presynaptic fibers. In hippocampal slices, both the stimulating and recording electrodes were placed in stratum radiatum of the CA1 region to record field EPSPs (fEPSPs) elicited by activation of Schaffer collateral-commissural fibers. To examine amygdala synaptic plasticity, a recording electrode was placed in the basolateral nucleus to record population responses elicited by a stimulating electrode in the lateral nucleus near the external capsule. In all experiments, we used a stimulation intensity that evoked $50 \%$ of the maximal response (determined for each slice). Presynaptic stimulation pulses were delivered once every $50 \mathrm{sec}$ in experiments on hippocampal slices and once every $20 \mathrm{sec}$ in amygdala slices. Hippocampal synaptic plasticity was investigated using a high-frequency stimulation protocol (two $1 \mathrm{sec}$ duration trains of $100 \mathrm{~Hz}$ stimulation delivered with an intertrain interval of $10 \mathrm{sec}$ ), a theta-pulse stimulation (TPS) protocol (single pulses delivered at $5 \mathrm{~Hz}$ ) consisting of 25, 150, or 900 stimulation pulses, or with three trains of a theta-burst stimulation (intertrain interval of $20 \mathrm{sec}$, each train consisted of 5 50-msec-long $100 \mathrm{~Hz}$ stimulation trains delivered once every 200 $\mathrm{msec})$. The induction of LTP in amygdala slices from wild-type and Rin $1^{-/-}$mice was examined using three trains of theta-burst stimulation (same as for hippocampus).

Statistical analysis. A two-way ANOVA with repeated measures was used to analyze the acquisition data from the water maze and rotarod tasks. Single-factor ANOVA, equivalent to an unpaired two-tailed $t$ test, was used to analyze fear conditioning, CTA, and time in training quadrant for the water maze probe trials; post hoc comparisons between quadrants were performed when there was an effect of quadrant. Planned comparisons using an unpaired two-tailed $t$ test were used to analyze LTP data.

\section{Results \\ Rin1 is expressed in mature forebrain neurons and is localized in dendrites}

We first determined that, similar to human RIN1 (Han et al., 1997), mouse Rin1 mRNA is expressed at highest levels in the brain with low or undetectable expression in most other tissues and moderate expression in testis (Fig. 1A). Subsequent analysis showed that expression of mouse Rin 1 message in the brain is restricted to the forebrain with notable enrichment in hippocampus, amygdala, striatum, and cortex (Fig. $1 B-F)$, consistent with human brain region expression results (data not shown). Rin1 expression was clearly evident in higher-resolution images of amygdala (Fig. 1G,H, dark field). No Rin1 mRNA was detected in mouse midbrain or hindbrain structures, including the thalamus (Fig. 1C,F) and cerebellum (data not shown). This pattern was suggestive of neuronal localization, and no expression was detected in glial cell-rich white matter tracts with low neuron density (Fig. $1 E$ ). Consistent with this finding, Rin 1 message was detected over mouse neurons (e.g., CA3 neurons) (Fig. 1I) but not over glial cell bodies (data not shown). Analysis of human hippocampal dentate gyrus revealed that RIN1 protein is found in the cell bodies and dendrites of granule cell neurons (Fig. $1 \mathrm{~J}, \mathrm{~K}$ ), implicating RIN1 in postsynaptic signal transduction. Immunohistochemical analysis of mouse forebrain sections confirmed the human tissue result that Rin 1 is expressed in neuronal cell bodies and dendrites (Fig. $1 L-N$ ). These observations do not, of course, exclude the possibility that there are low levels of RIN1 in axons.

Mouse embryos were examined to investigate developmental Rin1 expression. Rin1 message was undetectable by Northern blot using embryonic day 11 (E11), E15, and E17 embryonic message (data not shown). To specifically address the temporal regulation of Rin1 expression in brain, we analyzed sections from embryonic days 14 and 18 and from postnatal days $0,7,21$, and 56. Rin1 expression was undetectable in embryonic brain tissue and extremely weak in postnatal day 0 (P0) sections (data not shown). Expression was low at P7 (Fig. $1 B, C$, control, D), reached maximal levels by $\mathrm{P} 21$ (Fig. $1 E, F$ ), and was maintained at P56 (data not shown). This induction coincides with the onset of rapid synaptogenesis (Aghajanian and Bloom, 1967). These findings suggested that Rin1 may be dispensable for early brain development and morphogenesis but implicated Rin1 in a postsynaptic function of mature forebrain neurons. Notably, the expression profile of Rin 1 closely parallels that of several components of the PSD, a multiprotein complex involved in LTP and memory formation (Kennedy, 2000). These include PSD95 (Cho et al., 1992) and calmodulin kinase II $\alpha$ subunit (Cho et al., 1992), 


\section{A}

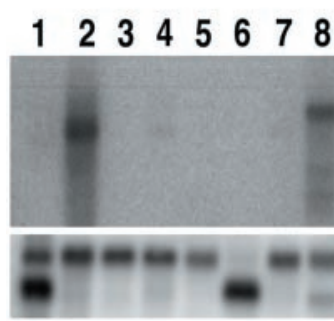

Rin1

Actin

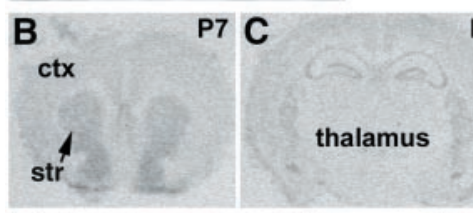

P7 D

P7
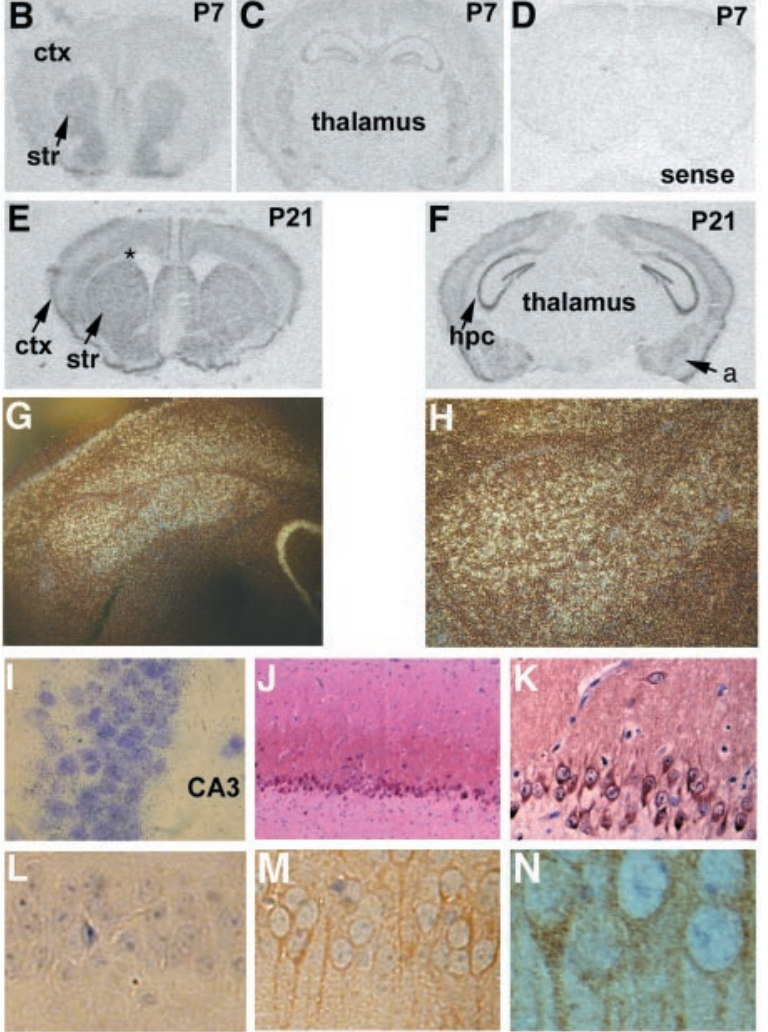

Figure 1. Expression of $\operatorname{Rin} 1$ message and localization of Rin 1 protein. $A$, A mouse multiple tissue Northern blot (Clontech) was hybridized with ${ }^{32} \mathrm{P}$-labeled cDNA probes for Rin 1 (top) and actin (bottom). Lane 1, Heart; lane 2, brain; lane 3, spleen; lane 4, lung; lane 5, liver; lane 6, skeletal muscle; lane 7 , kidney; and lane 8 , testis. $B-G, \operatorname{Rin} 1$ message is localized to mouse forebrain neurons. Wild-type mouse brain coronal sections were hybridized with a ${ }^{35} S$-labeled antisense Rin 1 RNA probe $(B, C, E-l)$ or sense probe (D). Autoradiographs indicate Rin $1 \mathrm{mRNA}$ in the cortex (ctx), striatum (str), amygdala (a), and hippocampus (hpc). Expression intensity increased between $\mathrm{P} 7(B, C)$ and P21 $(E, F)$. No expression was detected in the thalamus or in white matter tracts $\left.{ }^{*}\right) . G, H$, Ten and $25 \times$ dark-field images of amygdala showed clear expression through this region. I, Light-field analysis at $40 \times$ showed $\operatorname{Rin} 1 \mathrm{mRNA}$ localized over mouse CA3 neuronal nuclei. J, K, RIN1 protein was detected in cell bodies and dendrites but not the axonal mossy fibers of human hippocampal granule cells. Paraffin-embedded human coronal brain sections were subjected to immunohistochemistry with polyclonal anti-RIN1; J, $4 \times ; K$, $20 \times . L-N$, Mouse Rin 1 protein is expressed in the cell bodies and dendrites of CA1 hippocampal neurons. Paraffin-embedded coronal mouse brain sections were subjected to immunohistochemical staining with anti-Rin1 (polyclonal). Rin $1^{-1-}, L, 40 \times ;$ WT, M, 40×; WT, N, 100×.

although these show somewhat broader CNS distribution than RIN1.

$\operatorname{Rin}^{-/-}$mice are viable and appear to develop normally To examine the role of Rin 1 in the function of the adult brain, we generated a recombination targeting vector in which exons 2 through 7, encoding most of the ABL and RAS binding domains
A

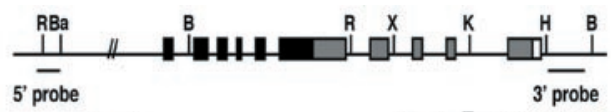

B
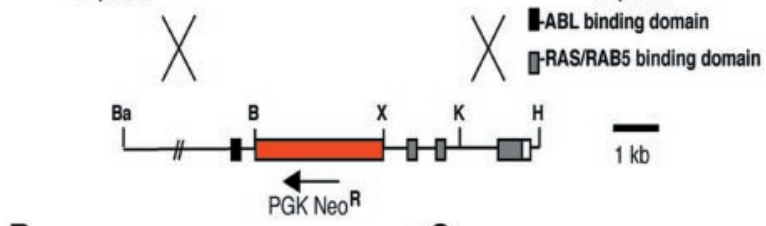

C

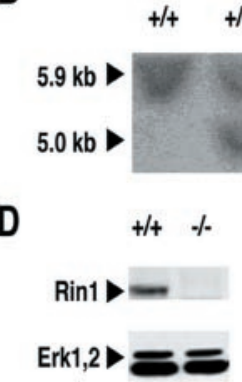

E

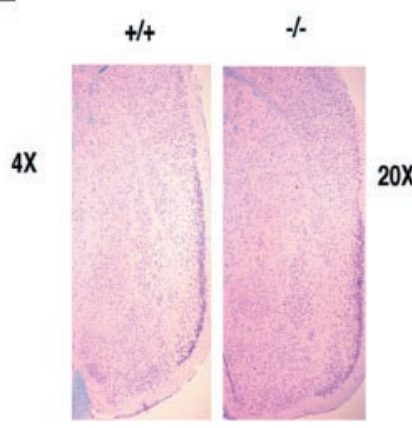

$\mathbf{F}$

$+/+$

$+$

$20 \mathrm{X}$
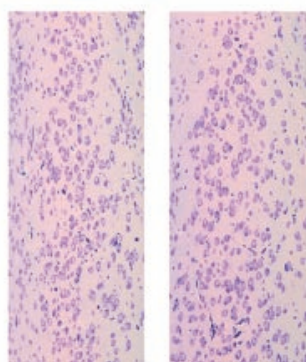

Figure 2. Generation of a targeted mutation in the mouse Rin 1 gene. $A$, Protein-genomic structure and targeting strategy. An $\sim 3 \mathrm{~kb}$ sequence encoding exons $2-7$ was replaced by an $\sim 2$ kb PGK promoter-driven neomycin resistance cassette. Restriction sites are as follows: $B$, Bg/ll; Ba, BamHI; H, Hindlll; K, Kpnl; R, EcoRl; X, Xbal. B, Southern blot analysis. Genomic tail DNA samples were digested with Bg/ll and hybridized with a 3' flanking probe. Rin 1 genotypes are indicated above each lane. C, Northern blot analysis. Total RNA (30 $\mu \mathrm{g})$ from the brains of mice of each genotype was hybridized with Rin 1 (top) or Gapdh (bottom) CDNA probes. D, Immunoblot analysis. Total protein $(60 \mu \mathrm{g})$ from forebrains of mutant $(-/-)$ and wild-type $(+/+)$ mice was blotted with anti-Rin1 (top) or anti-ERK 1, 2 (bottom). E, Kluver-Barrera-stained coronal brain sections of the amygdala of wild-type $(+/+)$ and $\operatorname{Rin} 1^{-/-}(-/-), 4 \times$. F, Same, $20 \times$.

of Rin1 (Fig. 2A), were replaced with a phosphoglycerate kinase promoter-driven neomycin resistance gene. Gene disruption was performed using an adaptation of established techniques. After the generation of transgenic F1 animals, deletion of the Rin 1 gene was confirmed by Southern blot (Fig. $2 B$ ), Northern blot (Fig. $2 C$ ), in situ hybridization (data not shown), immunoblot analysis of brain extracts (Fig. 2D), and immunohistochemical analysis of forebrain sections (Fig. $1 L, M$ ). Rin1 null mice were viable and fertile and were generated in the expected Mendelian ratio. Histological analysis of $\mathrm{Rin}^{-/-}$mice revealed no gross morphological abnormalities (data not shown). Furthermore, hematoxylinand eosin-stained, as well as Kluver-Barrera-stained, coronal brain sections of mutant mice were indistinguishable from wildtype mice, with no observable changes in neuron cell densities in the amygdala (Fig. 2E,F) or other forebrain regions (data not shown). 
A

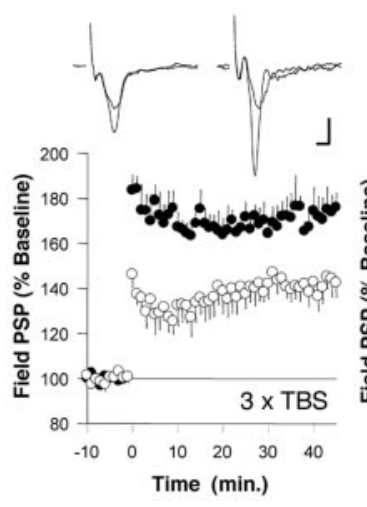

B

C
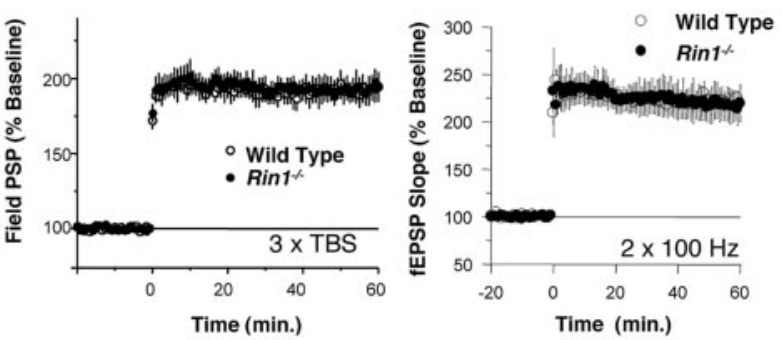

Figure 3. LTP is enhanced in the amygdala of $\operatorname{Rin} 1^{-1-}$ mice. $A$, The amount of amygdala LTP induced by a theta-burst stimulation protocol $(3 \times \mathrm{TBS})$ is enhanced in slices from $\operatorname{Rin} 1^{-1-}$ mice. Insets show extracellular responses elicited during baseline (smaller response) and 40 min after TBS in slices from wild-type (left set of traces) and Rin $1^{-1-}$ mice (right set of traces). Calibration bars: $2 \mathrm{msec}, 0.5 \mathrm{mV}$. B, The same TBS protocol used for amygdala, when applied to hippocampus slices, showed no difference with genotype. C, The amount of LTP induced by two trains of $100 \mathrm{~Hz}$ stimulation in slices from Rin $1^{-/-}$mice was indistinguishable from that seen in wild-type slices.

\section{Rin1 null animals have elevated amygdala LTP}

To examine whether Rin1 might have a role in the mechanisms underlying activity-dependent forms of synaptic plasticity, we examined wild-type and Rin1 ${ }^{-/-}$mice for LTP in amygdala and hippocampus, regions of the brain known to subserve emotional and spatial learning, respectively. We recorded population responses elicited in the basolateral amygdala nucleus after activation of presynaptic fibers by a stimulating electrode placed in the lateral amygdaloid nucleus (Brambilla et al., 1997; Rammes et al., 2000). Using a theta-burst protocol (TBS), we observed a striking enhancement of LTP in Rin $1^{-/-}$mice when compared with wildtype animals (Fig. 3A). The average amplitude of postsynaptic responses recorded $40-45 \mathrm{~min}$ after TBS was $142 \pm 6 \%$ of baseline in wild-type slices ( $n=4$ mice, 8 slices) and $174 \pm 8 \%$ of baseline in slices from $\operatorname{Rin} 1^{-/-}$mice $(n=4$ mice, 8 slices $)\left(t_{(6)}=\right.$ $-3.06 ; p<0.05)$. This robust elevation of amygdala LTP in mutant mice suggested that the Rin 1 protein might normally act as a negative regulator of synaptic plasticity in this region.

In hippocampal slices from $\operatorname{Rin} 1^{-1-}$ mice, we observed no alterations in either basal synaptic transmission or paired-pulse facilitation (data not shown). To examine whether LTP might be altered in this brain region, we compared the amount of potentiation induced by a TBS stimulation protocol equivalent with that used for amygdala analysis. The fEPSP values for wild-type (192 $\pm 9 \% ; n=3$ mice, 6 slices $)$ and Rin1 ${ }^{-/-}(194 \pm 8 \% ; n=3$ mice, 6 slices) samples showed no difference $\left(t_{(4)}=0.13 ; p>\right.$ 0.05) (Fig. 3B). We also examined levels of LTP induced with another protocol consisting of two, 1-sec-long trains of $100 \mathrm{~Hz}$ presynaptic fiber stimulations (intertrain interval of $10 \mathrm{sec}$ ). This protocol induced nearly identical amounts of LTP in slices from wild-type $(222 \pm 7 \% ; n=4,7$ slices $)$ and $\operatorname{Rin}^{-1-}(217 \pm 24 \%$; $n=6,11$ slices) mice $\left(t_{(4)}=0.16 ; p>0.05\right)$ (Fig. $\left.3 C\right)$.

We considered the possibility that Rin 1 might have a modulatory role in hippocampal LTP induced by less intense patterns of synaptic activation and therefore examined the effects of multiple TPS protocols. The induction of LTP by TPS showed a marked dependence on the train duration, as expected (Thomas et al., 1996). To assess stimulation protocol-dependent effects, we tested short (25 pulses), intermediate (150 pulses), and long (900 pulses) trains of TPS ( $5 \mathrm{~Hz}$ stimulation) on synaptic strength in slices from wild-type and $R$ in $1^{-1-}$ mice (fEPSPs recorded 40-45 min after stimulation). Short and long TPS trains failed to induce substantial LTP $(>120 \%$ of baseline) in either wild-type or Rin1 $1^{-1-}$ mice [short, WT ( $n=3,7$ slices), $109 \pm 1.8 \%$; $\operatorname{Rin}^{-/-}(n=3$, 6 slices $), 117 \pm 6.6 \%$; long, WT ( $n=4,7$ slices), $127 \pm 13 \%$; Rin1 $^{-/-}(n=6,10$ slices $\left.), 123 \pm 11 \%\right]$. Although an intermediate train of TPS induced LTP, the responses from wild-type mice (fEPSP, $195 \pm 11 \% ; n=4,7$ slices) and $R$ in $1^{-1-}$ mice (fEPSP, $178 \pm 13 \%$ of baseline; $n=6,11$ slices) were again equivalent $\left(t_{(8)}=0.92 ; p>0.05\right)$. Therefore, over a range of intensities including subthreshold induction protocols, the mutant mice showed no observable change in hippocampal LTP. It remains possible, of course, that the mutant mice have subtle hippocampal LTP alterations that are not readily detectable. In either event, the results suggest a distinction between Rin1 function in the synaptic physiology of the hippocampus and that of the amygdala, in which a pronounced enhancement in plasticity was observed.

\section{Fear conditioning is enhanced in Rin1-deficient mice}

Based on LTP results indicating elevated amygdala activity, we investigated associative amygdala-dependent emotional memory using an auditory cued fear conditioning protocol. In this test, animals learn to fear a conditioned stimulus (CS) (tone) when paired with an aversive unconditioned stimulus (US) [a mild foot shock $(0.5 \mathrm{~mA})]$. Fear of the CS is measured as the percentage of time an animal freezes (no movement other than respiration). Fear is elicited during reexposure to the CS and is believed to involve the transit of information from the auditory thalamus and cortex to the amygdala, in which previous changes in synaptic plasticity (established during training) underlie fear memories (LeDoux, 2000).

To assess long-term memory, cued conditioning was measured $48 \mathrm{hr}$ after training. The Rin $1^{-/-}$mice showed a striking enhancement in freezing to the auditory cue $\left(\operatorname{Rin} 1^{-1-}, 45.0 \pm\right.$ 5.8; WT, $26.3 \pm 4.4 ; F_{(1,32)}=6.6 ; p<0.05$ ) (Fig. $4 A$ ). Analysis of pre-CS (PCS) freezing revealed no significant difference between mutant and control animals $\left(\operatorname{Rin}^{-1-}, 16.3 \pm 2.7\right.$; WT, $10.2 \pm$ $\left.3.0 ; F_{(1,32)}=2.2 ; p>0.05\right)$ (Fig. $4 A$ ). As an assay of short-term memory, we tested a separate group of animals by measuring freezing to the auditory cue $30 \mathrm{~min}$ after training. Again, the Rin $1^{-1-}$ mice demonstrated enhanced freezing to the tone $\left(\right.$ Rin $^{-/-}, 54.4 \pm 5.8$; WT, $\left.34.9 \pm 5.5 ; F_{(1,32)}=6.0 ; p<0.05\right)$ (Fig. $4 B)$ but not during the PCS $\left(\operatorname{Rin}^{-/-}, 18.4 \pm 3.5\right.$; WT, $11.8 \pm 2.5$; $\left.F_{(1,32)}=2.3 ; p>0.05\right)$.

Importantly, mutant and wild-type mice showed equal baseline freezing $\left(\operatorname{Rin}^{-/-}, 4.85 \pm 0.88\right.$; WT, $4.76 \pm 1.05 ; F_{(1,66)}=$ $0.004 ; p>0.05)$ and baseline activity $\left(\operatorname{Rin} 1^{-/-}, 27.6 \pm 1.8\right.$; $\left.\mathrm{WT}, 25.4 \pm 2.6 ; F_{(1,66)}=0.44 ; p>0.05\right)$. In addition, we found no difference in baseline freezing to the tone between wildtype $(7.2 \pm 1.8 ; n=35)$ and $\operatorname{Rin} 1^{-1-}(9.0 \pm 1.8 ; n=33)$ mice $\left(F_{(1,66)}=0.458 ; p>0.05\right)$. Finally, we evaluated pain perception by the mice during conditioning (Anagnostaras et al., 2000) to rule out possible contributions to assay results. We detected no differences between wild-type and mutant mice in 
unconditioned response (jump velocity) to shock over a range of intensities $(0.2$ $\mathrm{mA}, \operatorname{Rin}^{-/-}, 13.4 \pm 3.3 \mathrm{~cm} / \mathrm{sec}$; WT, $12.4 \pm 1.5 \mathrm{~cm} / \mathrm{sec} ; F_{(1,10)}=0.11 ; p>$ $0.05 ; 0.5 \mathrm{~mA}, \operatorname{Rin1}^{-/-}, 18.1 \pm 1.4 \mathrm{~cm} /$ $\mathrm{sec}$; WT, $21.7 \pm 1.3 \mathrm{~cm} / \mathrm{sec} ; F_{(1,54)}=3.5$; $p>0.05 ; 0.75 \mathrm{~mA}, \operatorname{Rin}^{-/-}, 34.1 \pm 5.1$ $\mathrm{cm} / \mathrm{sec}$; WT, $38.0 \pm 4.2 \mathrm{~cm} / \mathrm{sec} ; F_{(1,14)}=$ 0.35; $p>0.05$ ) (Fig. 4C). Together with the elevation in amygdala LTP, these data suggested that the learning enhancement seen in $\operatorname{Rin} 1^{-/-}$mice was the result of alterations in the process of amygdala-dependent memory formation.

\section{Conditioned taste aversion is elevated in} $\operatorname{Rin1}^{-/-}$mice

To confirm that the altered behavior reflected elevated amygdala-dependent learning, we subjected mice to an independent test of amygdala function, CTA

(Yamamoto et al., 1994). In this assay, animals learn to avoid an otherwise favorable novel taste (saccharin, CS) when it is paired with the injection of a malaise-inducing agent ( $\mathrm{LiCl}, \mathrm{US})$. Animals were injected ( $2 \%$ body weight) with PBS (control) or $0.3 \mathrm{M}$ LiCl. Both wild-type and Rin1 null mice showed a significant induction of CTA compared with PBS injected controls $\left(\right.$ Rin $\left.^{-1-}, F_{(1,27)}=144.3 ; p<0.05 ; \mathrm{WT}, F_{(1,30)}=35.6 ; p<0.05\right)$ (Fig. 5). Rin1 null mice, however, had a much higher CTA (lower aversion index) than wild types, indicating enhanced aversive memory $\left(\right.$ Rin $^{-/-}, 0.24 \pm 0.03$; WT, $0.39 \pm 0.04 ; F_{(1,27)}=8.9$; $p<0.05$ ) (Fig. 5). Wild-type and mutant animals responded equivalently (crouching, lying on belly, inactivity, and rearing) to treatment with $\mathrm{LiCl}$. These results reinforce the conclusion, drawn from LTP and fear conditioning experiments, that amygdala-dependent associative learning is enhanced in the absence of Rin1.

\section{Mutant mice show no deficit in hippocampal-dependent learning}

Although multiple LTP protocols revealed no change in hippocampal function, we evaluated hippocampus-controlled behavior to probe for possible effects not apparent by electrophysiological measurements. The Morris water maze (Morris et al., 1982; Cho et al., 1999), is a particularly sensitive test of hippocampal-dependent spatial learning. In this task, animals learn to find a submerged hidden platform using visual cues outside the pool. During acquisition, mice were given two trials per day (30 sec ITI) for $12 \mathrm{~d}$. No differences were observed in floating, thigmotaxic behavior, or swimming speed $\left(\operatorname{Rin} 1^{-/-}, 17.9 \pm 1.2\right.$ $\mathrm{cm} / \mathrm{sec}$; WT, $\left.19.9 \pm 0.9 \mathrm{~cm} / \mathrm{sec} ; F_{(1,15)}=1.7 ; p>0.05\right)$. All animals showed decreased escape latencies with successive trials $\left(F_{(11,165)}=7.0 ; p<0.05\right)$ (Fig. 6A), demonstrating learning of the platform position, and no difference was found between Rin $1^{-1-}$ and wild-type littermates $\left(F_{(1,15)}=0.9 ; p>0.05\right)$. Escape latency, however, is not an ideal indicator of spatial learning because mice can improve their performance using nonspatial strategies to locate the platform (Brandeis et al., 1989). We therefore assessed learning by measuring time spent searching in the training quadrant during probe trials (platform removed) that were performed $1 \mathrm{hr}$ after a training session and initiated with a platform cue. This protocol examines a combination of shortand long-term memory. Both mutant and wild-type animals
B

c
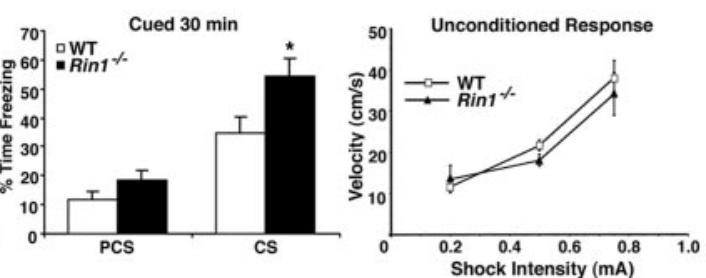

Shock Intensity $(\mathrm{mA})$

Figure 4. Amygdala-dependent learning is enhanced in $\operatorname{Rin} 1^{-/-}$mutants. A, Animals ( $\operatorname{Rin} 1^{-/-}, n=16 ; \mathrm{WT}, n=18$ ) were tested for cued freezing $48 \mathrm{hrs}$ after training with a $0.5 \mathrm{~mA}$ shock in the presence of a $3 \mathrm{~min}$ tone (CS) in a neutral cage. There was

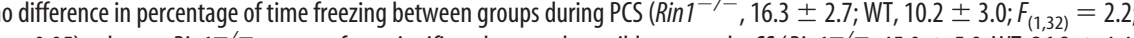
$p>0.05)$, whereas $\operatorname{Rin} 1^{-/}$mutants froze significantly more than wild types to the $C S\left(\operatorname{Rin} 1^{-/-}, 45.0 \pm 5.8 ; \mathrm{WT}, 26.3 \pm 4.4\right.$ (1) min after training. There was no difference in percentage of time freezing between groups during the PCS ( $\operatorname{Rin} 1^{-1-}, 18.4 \pm$ SEM) to 2 sec shocks at $0.2 \mathrm{~mA}$ (WT, $\left.n=7 ; \operatorname{Rin}^{-/}, n=5\right), 0.5 \mathrm{~mA}\left(\mathrm{WT}, n=29 ; \operatorname{Rin}^{-/-}, n=27\right)$, or $0.75 \mathrm{~mA}$ (WT, $n=7$; $\left.\operatorname{Rin} 1^{-1-}, n=9\right) .{ }^{*} p<0.05$, indicates a significant difference between wild-type and mutant under the same conditions.

spent an equivalent percentage of time searching in the training quadrant on probe trials conducted on day $8\left(\operatorname{Rin1}^{-1-}, 39.2 \pm\right.$ 3.3 ; WT, $\left.32.7 \pm 4.4 ; F_{(1,15)}=1.4 ; p>0.05\right)$, day $10\left(\right.$ Rin1 $^{-/-}$, $\left.44.5 \pm 4.4 ; \mathrm{WT}, 38.3 \pm 4.8 ; F_{(1,15)}=0.9 ; p>0.05\right)$ and day 12 $\left(\right.$ Rin $^{-1-}, 39.2 \pm 4.7$; WT, $\left.39.7 \pm 4.8 ; F_{(1,15)}=0.005 ; p>0.05\right)$. Data from day 12 demonstrate that both $\operatorname{Rin}^{-/-}$mice and control mice learned the platform location, spending significantly more time searching in the training quadrant than in the other quadrants $\left(\operatorname{Rin} 1^{-1-}, F_{(3,32)}=6.6 ; p<0.05 ; \mathrm{WT}, F_{(3,28)}=5.5 ; p<\right.$ 0.05) (Fig. 6B).

Mice were also tested using a modified water maze protocol (four trials per day; $30 \mathrm{sec}$ ITI) that selectively examined longterm memory by performing probe trials $24 \mathrm{hr}$ after training without platform cueing. Mice were trained for $6 \mathrm{~d}$ with probe trials conducted before training on day 5 and on day 7. Again, we found no differences between wild-type and mutant mice. All animals showed decreased escape latencies across trials $\left(F_{(6,135)}=\right.$ $26.0 ; p<0.05$ ) (Fig. $6 C$ ), and no differences were found between

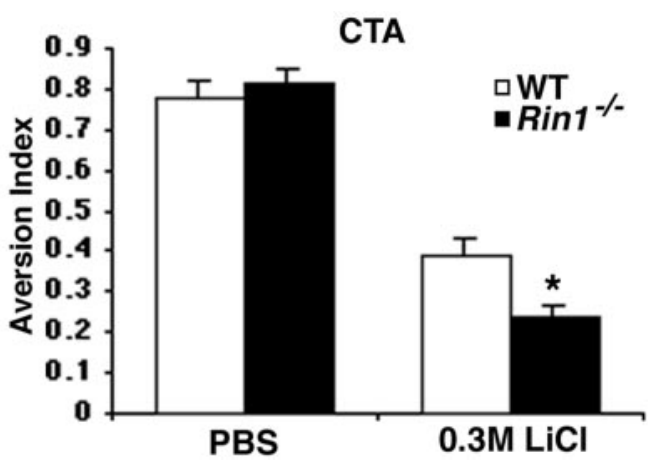

Figure 5. Conditioned taste aversion. Saccharin-flavored water was paired with an intraperitoneal injection ( $2 \%$ body weight) of PBS ( $\operatorname{Rin} 1^{-/-}, n=15$; WT, $n=17$ ) or $0.3 \mathrm{~m} \mathrm{LiCl}$ $\left(\operatorname{Rin} 1^{-/-}, n=14 ; \mathrm{WT}, n=15\right)$. Twenty-four hours later, mice were tested for saccharin aversion. Aversion indices were calculated as follows: (saccharin water consumed/(saccharin water consumed + unflavored water consumed $))$. $\operatorname{Rin} 1^{-1-}$ mutants $\left(F_{(1,27)}=144.3 ; p<\right.$ $0.05)$ and wild types $\left(F_{(1,30)}=35.6 ; p<0.05\right)$ both acquired a significant aversion to saccharin when paired with $0.3 \mathrm{~m} \mathrm{LiCl}$. Rin $1^{-1-}$ mutants, however, had a significantly higher aversion index than wild types ( $\operatorname{Rin} 1^{-1-}, 0.24 \pm 0.03$; WT, $\left.0.39 \pm 0.04 ; F_{(1,27)}=8.9 ; p<0.05\right)$. PBS-injected mutants and wild types exhibited equivalent preference for saccharin-flavored water $\left(F_{(1,30)}=0.36 ; p>0.05\right)$. ${ }^{*} p<0.05$, indicates significant difference between wild type and mutant under the same conditions. 
A

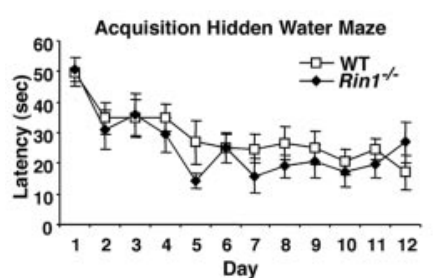

C

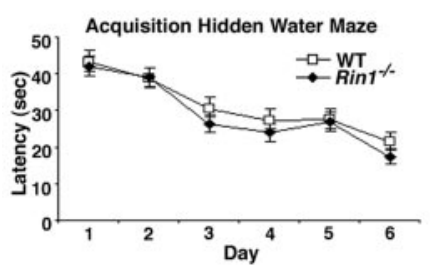

B

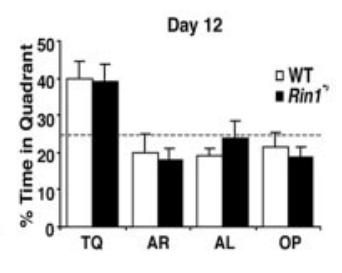

D

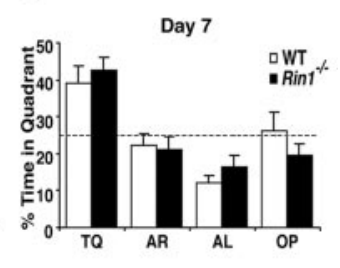

A

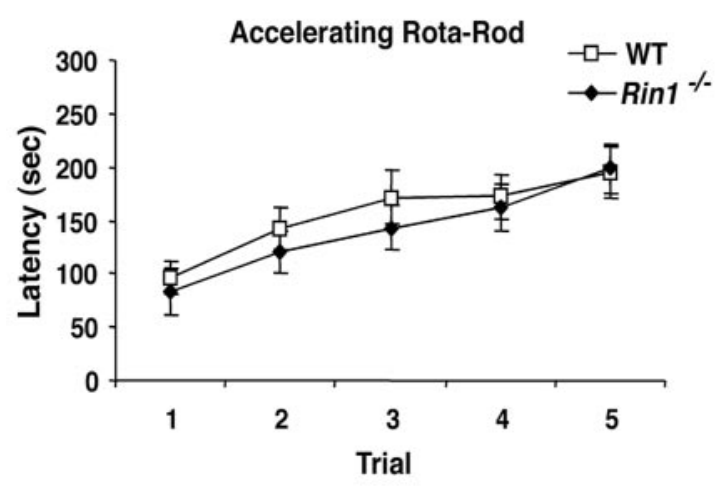

B

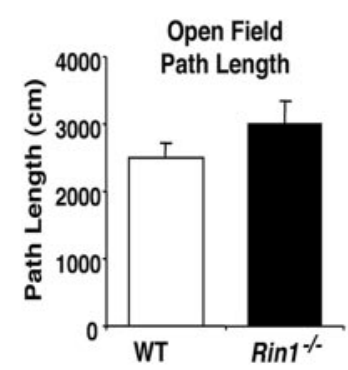

C

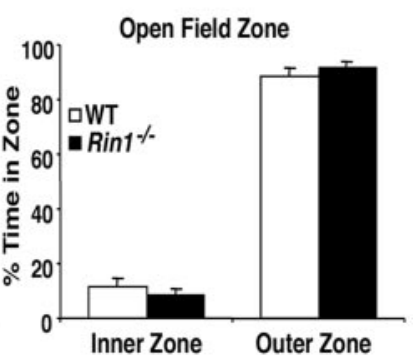

Figure 6. Hippocampus-dependent learning appears unaffected by deletion of Rin1. $A$, $\operatorname{Rin} 1^{-/-}$mutants $(n=9)$ and wild-type controls $(n=8)$ were trained for $12 \mathrm{~d}$ with two trials per day ( 30 sec ITI). The average \pm SEM latency to reach the hidden platform is plotted versus training day. Escape latencies decreased across days for both groups $\left(F_{(11,165)}=7.0 ; p<0.05\right)$, with no difference between mutants and wild types $\left(F_{(1,15)}=0.9 ; p>0.05\right)$. B, During the day 12 probe trial, both mutants $\left(F_{(3,32)}=6.6 ; p<0.05\right)$ and wild types $\left(F_{(3,28)}=5.5 ; p<0.05\right)$ searched selectively and spent significantly more time in the training quadrant than in any other quadrant (Fisher's PLSD; $p<0.05$ ). There was no statistical difference between groups in time spent searching in the training quadrant $\left(F_{(1,15)}=0.005 ; p>0.05\right)$. C, Rin $1^{-1-}$ mice $(n=17)$ and wild-type controls $(n=12)$ were trained for $6 \mathrm{~d}$ with four trials per day ( 30 sec ITI). The average \pm SEM latency to reach platform is plotted versus training day. Escape latencies decreased across days for both groups $\left(F_{(6,135)}=26.0 ; p<0.05\right)$, with no differences between mutant and wild types $\left(F_{(1,27)}=0.9 ; p>0.05\right)$. D, During the day 7 probe trial, conducted 24 hr after training to assess long-term memory, both mutants $\left(F_{(3,64)}=14.0 ; p<0.05\right)$ and wild types $\left(F_{(3,44)}=9.0 ; p<0.05\right)$ searched selectively and spent significantly more time in the training quadrant than in any other quadrant (Fisher's PLSD; $p<0.05$ ). There was no statistical difference between groups in time spent searching in the training quadrant $\left(F_{(1,27)}=0.38 ; p>\right.$ $0.05)$. Dashed line indicates random search ( $25 \%$ in each quadrant). $T Q$, Training quadrant; $A R$, adjacent right; $A L$, adjacent left; $O P$, opposite quadrant.

Rin $1^{-/-}$and wild-type animals $\left(F_{(1,27)}=0.9 ; p>0.05\right)$. Mutants and wild types spent equivalent times searching in the training quadrant during probe trials on day $5\left(\operatorname{Rin1}^{-1-}, 31.0 \pm 2.9 ; \mathrm{WT}\right.$, $\left.31.1 \pm 5.5 ; F_{(1,27)}=0.0002 ; p>0.05\right)$ and on day $7\left(\operatorname{Rin}^{-1-}\right.$, $\left.42.7 \pm 3.4 ; \mathrm{WT}, 39.2 \pm 4.5 ; F_{(1,27)}=0.38 ; p>0.05\right)$. By day 7 , both $R$ Rin $1^{-1-}$ and control mice learned the platform location, spending significantly more time searching in the training quadrant than in the other quadrants $\left(\operatorname{Rin1}^{-1-}, F_{(3,64)}=14.0 ; p<\right.$ 0.05 ; WT, $F_{(3,44)}=9.0 ; p<0.05$ ) (Fig. $6 D$ ). These data suggest that $\operatorname{Rin}^{-(3,4)}$ mice are grossly normal in hippocampusdependent behaviors. The analyses do not, of course, rule out the possibility of alterations that are relatively insensitive to these assays.

\section{$\operatorname{Rin} 1^{-/-}$mice display normal motor learning, anxiety, and} exploratory behavior

We next investigated whether $\operatorname{Rin}^{-1-}$ mice were affected in their performance of standard behavioral tasks to assess the possibility that other factors may have contributed to our findings. Animals were tested on an accelerating rotarod $(4-40 \mathrm{rpm}$ in $300 \mathrm{sec})$ to determine whether the Rin1 deletion affected motor function or motor learning. Both $\mathrm{Rin}^{-1-}$ and wild-type mice showed an increased latency to fall across five trials $\left(F_{(4,84)}=17.4 ; p<0.05\right)$, and there was no statistical difference between the two groups $\left(F_{(1,21)}=0.3 ; p>0.05\right)$ (Fig. $\left.7 \mathrm{~A}\right)$, indicating normal motor skills. This finding is consistent with the observation that Rin1 expres-

Figure 7. Rin1 mutants have normal motor learning and open field performance. A, Accelerating rotarod. Wild-type $(n=12)$ and $\operatorname{Rin} 1^{-1-}(n=11)$ mice were given five trials in an accelerating rotarod ( $4-40 \mathrm{rpm}$ in $5 \mathrm{~min}$ ) during a single day. All subjects showed an increased latency to fall across trials $\left(F_{(4,84)}=17.4 ; p<0.05\right)$. In addition, both groups of animals fell off the rotating rod at the same time, indicating equivalent learning rates across trials $\left(F_{(4,84)}=\right.$ $0.4 ; p>0.05)$, with no effect of genotype $\left(F_{(1,21)}=0.3 ; p>0.05\right)$. B, Open field path length. Mice were placed in the center of a white circular arena $(60 \mathrm{~cm}$ in diameter) and tracked for 5 min. Mean path length for mutant $(n=12 ; 2992 \pm 352 \mathrm{~cm})$ and wild type $(n=14 ; 2501 \pm$ $215 \mathrm{~cm})$ were equivalent $\left(F_{(1,24)}=1.5 ; p>0.05\right)$. C, Open field inner and outer zone exploratory behavior. Mutant and wild-type mice were equivalent in percentage of time exploring the inner and outer zones $\left(F_{(1,24)}=0.5 ; p>0.05\right)$.

sion is undetectable in the cerebellum, a region required for motor learning (Chen et al., 1995). Animals were also subjected to the hanging wire test, to ascertain muscle strength, and again no difference was observed between groups (latency to fall, $\operatorname{Rin}^{-1-}$, $\left.43.1 \pm 8.9 \mathrm{sec} ; \mathrm{WT}, 47.0 \pm 17 \mathrm{sec} ; F_{(1,14)}=0.04 ; p>0.05\right)$.

$\operatorname{Rin}^{-1-}$ mice displayed activity levels equivalent to wild-type littermate controls when locomotion was measured in an open field test (path length, Rin1 ${ }^{-\prime-}, 2992 \pm 352 \mathrm{~cm}$; WT, $2501 \pm 215$ $\left.\mathrm{cm} ; F_{(1,24)}=1.5 ; p>0.05\right)$ (Fig. $7 B$ ). Furthermore, both groups of mice spent equivalent amounts of time investigating the inner and outer zones of the open field $\left(F_{(1,24)}=0.5 ; p>0.05\right)$ (Fig. $7 C$ ). These results indicate no difference between $\operatorname{Rin}^{-1-}$ and wild-type littermates in exploratory behavior, which is also an indicator of general anxiety (Crawley, 1985).

\section{Endogenous forebrain RIN1 binds to RAS}

RIN1 and RAF1 each have high specificity and strong affinity for activated RAS (Herrmann et al., 1996; Wang et al., 2002), and the two effector proteins show competitive binding in assays with purified proteins and in transfected cells (Wang et al., 2002). To evaluate the potential for endogenous RIN1 to bind RAS in neurons, we fractionated extract prepared from human forebrain tissue. RIN1 was found in the cytoplasm and plasma membrane 
A

B
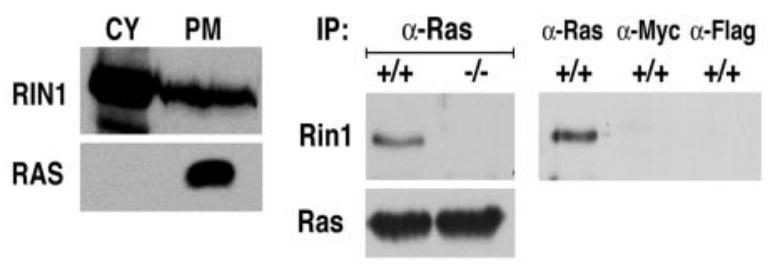

Figure 8. Rin1 engagement with Ras in forebrain. A, Subcellular localization of RIN1 protein. Human forebrain extracts were prepared in hypotonic solution and separated into cytosolic and membrane fractions (see Materials and Methods). Membranes were further separated over a sucrose gradient into plasma membrane and microsomal fractions. Cytosolic $(C Y)$ and plasma membrane (PM ) fractions ( $60 \mu \mathrm{g}$ of total protein) were subjected to immunoblot analysis with polyclonal anti-RIN1 (top) or polyclonal anti-RAS (bottom). B, Endogenous Ras and Rin1 binding. Ras protein was immunoprecipitated from wild-type and $\operatorname{Rin} 1^{-1-}$ mouse forebrain tissue extracts, and this material was then immunoblotted with anti-Rin1 (left two lanes). Mock immunoprecipitations, using anti-Myc or Anti-Flag agarose beads, showed no Rin 1 material (right panel), as expected.

fractions (Fig. 8A). These findings are consistent with a model of regulated RIN1 recruitment to activated RAS on the plasma membrane, similar to the established mechanism of RAF recruitment and activation.

We next determined that immunoprecipitation of Ras proteins from mouse forebrain resulted in the copurification of Rin1 (Fig. $8 B$ ). The anti-Rin 1 reactive material was absent from a parallel sample of $R i n 1^{-/-}$brain extract, confirming the identification. To rule out the possibility that Rin1 was adhering nonspecifically to the agarose beads, we performed parallel pull-down assays with anti-Flag and anti-Myc beads. No Rin 1 was detectable (Fig. $8 \mathrm{~B}$ ). The detection of Ras-engaged Rin 1, the first demonstration of binding between endogenous RAS and an effector in brain, demonstrates a significant basal level of active RAS in normal functioning forebrain. It is also consistent with a role for RIN1 as both RAF competitor and downstream signal effector.

\section{Discussion}

Rin $1^{-/}$animals showed enhancement of aversive learning and memory based on multiple independent sensory inputs (auditory and gustatory). These behaviors are dependent on amygdala, the emotion-processing region of the brain, although they are influenced by other forebrain regions, such as cortex. A concomitant increase in amygdala LTP strongly supports a critical function for Rin 1 in this region of the brain. Although Rin1 expression in hippocampus is comparable with that seen in amygdala, we detected no significant alterations in primarily hippocampaldependent tasks or in hippocampal LTP. The enhanced amygdala-dependent learning of the Rin1 mutant is strikingly complementary to the reported amygdala-specific deficits of Grf1 mutant animals (Brambilla et al., 1997), suggesting that this region may be particularly sensitive to changes in RAS pathway signal intensity. Another example of a brain region-specific phenotype is an Erk1 mutation, which produced divergent changes in the nucleus accumbens (LTP increase) and hippocampus (LTP decrease), although no differences in regional biochemistry were observed (Mazzucchelli et al., 2002). The fact that some neuronal gene disruptions can result in localized alterations, despite a wider pattern of expression, may reflect differences in signaling components (i.e., splice variants or posttranslational modifications), as well as region-specific regulatory or compensatory pathways (i.e., differences in signal buffering). The relative involvement of inhibitory versus excitatory neurons, which varies

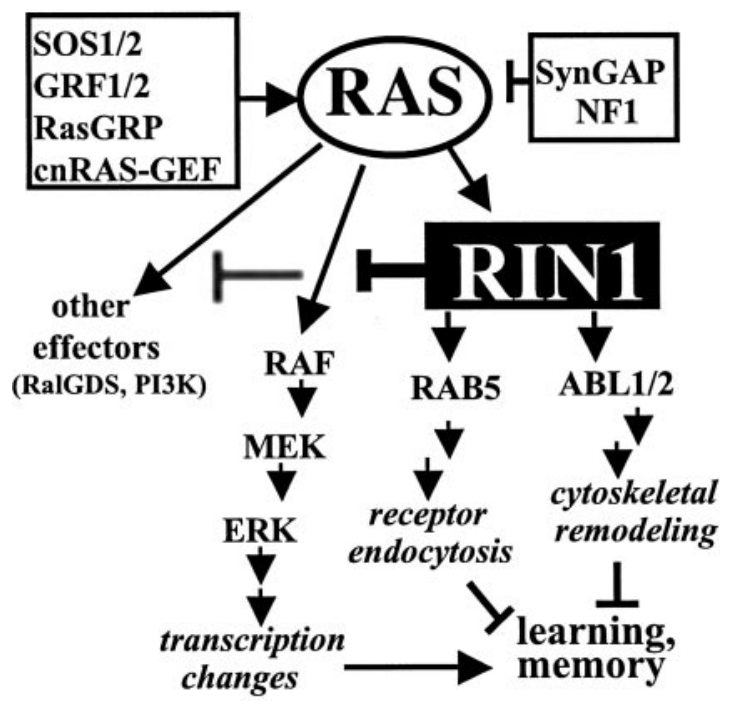

Figure 9. Model of RIN1 action in RAS-mediated pathways controlling learning and memory. Neurotransmitter receptor stimulation leads to activation of RAS exchange factors (SOS, GRF, RasGRP, and cnRAS-GEF) in postsynaptic cells. Negative regulators of RAS in neurons include the GTPase-activating proteins NF1 and SynGAP. RAS proteins signal through RAF proteins to initiate the MAP kinase cascade, resulting in transcription changes required for longterm memory. RIN1 inhibits this pathway by competing with RAF (and probably other RAS effectors, such as PI3K and RaIGDS) for the effector binding site on RAS. RIN1 functions through two downstream pathways: (1) activation of RAB5 to promote receptor endocytosis and downregulation and (2) activation of $A B L 1$ and $A B L 2$ tyrosine kinases, leading to cytoskeletal remodeling involved in structural changes that may diminish synaptic strength of excitatory cells.

among regions, may be another contributing factor in localized phenotypes.

The increase in both LTP and memory resulting from the Rin $1^{-/-}$mutation suggests a negative modulating role for the RAS effector RIN1 in normal learning and memory. RAS activation can be triggered by multiple guanine nucleotide exchange factors, some of which are expressed primarily in the brain (Shou et al., 1992; Fam et al., 1997; Ebinu et al., 1998; Pham et al., 2000) (Fig. 9). These RAS activators respond to signaling (tyrosine phosphorylation and adaptor protein recruitment, or the increased production of cyclic nucleotides, $\mathrm{Ca}^{2+}$, and diacylglycerol) that can be mediated by neurotransmitter receptors. RAS activation is in turn attenuated by GTPase activating proteins, including SynGAP and NF1, which are expressed in neurons.

The biochemical properties of RIN1 suggest three mechanisms through which it might inhibit RAS-dependent neuronal plasticity (Fig. 9). First, RIN1 can effectively compete with RAF proteins for binding to activated RAS in vitro and in vivo (Wang et al., 2002), and we demonstrated in this study that RIN1 is engaged with RAS proteins in brain. The loss of RIN1 could, therefore, increase signaling through RAF pathways involved in changes required for long-term memory and plasticity of excitatory neurons (for review, see Weeber and Sweatt, 2002). In the same vein, loss of RIN1 might also promote signaling by other RAS effectors, such as phosphatidylinositol 3-kinase which has been implicated in synaptic plasticity in amygdala (Lin et al., 2001). In normal cells, the plasma membrane availability (and RAS accessibility) of RIN1 is regulated by binding to 14-3-3 (Wang et al., 2002), itself a protein implicated in plasticity (Philip et al., 2001).

Second, RIN1 enhances signaling from ABL1 (Afar et al., 1997) and ABL2 (Hu and Colicelli, unpublished data). These tyrosine kinases, which regulate cytoskeletal remodeling, have 
been implicated in neuron function (Koleske et al., 1998). In addition, ABL2 is enriched in the CNS and is localized to dendritic spines (Wang et al., 2001) in which cytoskeletal changes may serve to modify synapses (by extension or retraction of dendritic spines) in response to depolarization. The loss of RIN1 may reduce, or perhaps redirect, this tyrosine kinase pathway in a way that enhances plasticity of excitatory neurons and/or blocks plasticity of inhibitory neurons. Third, RIN1 acts in part to activate RAB5, via a RAS-mediated pathway, and promote receptor endocytosis (Tall et al., 2001). In this context, the loss of RIN1 might lead to a reduction in receptor downregulation and a prolonged excitatory response. These multiple RIN1 functions may act coordinately as a check on neuronal plasticity, a dynamic process that involves the evaluation of incoming signals for short-term synaptic changes and potential long-term incorporation. The Rin1 null mutation resets this equilibrium in favor of memory formation.

This is the first direct genetic demonstration of RAS effector involvement in neuronal plasticity (other RAS-binding effector gene disruptions are highly pleiotropic and typically lethal), and it reveals a previously unappreciated connection between RAS and other signaling components implicated in learning (e.g., ABL proteins). In addition, this study represents the first report supporting a role for RAS signaling in short-term memory.

The Rin1 mutant represents a rare instance of elevated learning and memory that is experimentally accessible to both in vitro and in vivo analyses. This model system should be particularly insightful for studies of amygdala function, which has been shown to reflect genetic variations in humans (Hariri et al., 2002). It also should be of value for understanding alterations in fear and emotion learning associated with human psychiatric disorders that are characterized by increased excitatory activity in the amygdala or in amygdala-dependent circuits (Schauz and Koch, 2000; Benes and Berretta, 2001; Berretta et al., 2001) and may provide insights into mechanisms of substance addiction that involve amygdala functions (Kruzich and See, 2001; Fuchs et al., 2002; Kantak et al., 2002).

\section{References}

Afar DE, Han L, McLaughlin J, Wong S, Dhaka A, Parmar K, Rosenberg N, Witte ON, Colicelli J (1997) Regulation of the oncogenic activity of BCR-ABL by a tightly bound substrate protein RIN1. Immunity 6:773-782.

Aghajanian GK, Bloom FE (1967) The formation of synaptic junctions in developing rat brain: a quantitative electron microscopic study. Brain Res 6:716-727.

Anagnostaras SG, Josselyn SA, Frankland PW, Silva AJ (2000) Computerassisted behavioral assessment of Pavlovian fear conditioning in mice. Learn Mem 7:58-72.

Atkins CM, Selcher JC, Petraitis JJ, Trzaskos JM, Sweatt JD (1998) The MAPK cascade is required for mammalian associative learning. Nat Neurosci 1:602-609.

Benes FM, Berretta S (2001) GABAergic interneurons: implications for understanding schizophrenia and bipolar disorder. Neuropsychopharmacology 25:1-27.

Berretta S, Munno DW, Benes FM (2001) Amygdalar activation alters the hippocampal GABA system: "partial" modelling for postmortem changes in schizophrenia. J Comp Neurol 431:129-138.

Bliss TV, Collingridge GL (1993) A synaptic model of memory: long-term potentiation in the hippocampus. Nature 361:31-39.

Blum S, Moore AN, Adams F, Dash PK (1999) A mitogen-activated protein kinase cascade in the CA1/CA2 subfield of the dorsal hippocampus is essential for long-term spatial memory. J Neurosci 19:3535-3544.

Bourtchuladze R, Frenguelli B, Blendy J, Cioffi D, Schutz G, Silva AJ (1994) Deficient long-term memory in mice with a targeted mutation of the cAMP-responsive element-binding protein. Cell 79:59-68.

Brambilla R, Gnesutta L, Minichiello L, White G, Roylance AJ, Herron CE,
Ramsey W, Wolfer DP, Cestari V, Rossi-Arnaud C, Grant SG, Chapman PF, Lipp HP, Sturani E, Klein R (1997) A role for the Ras signalling pathway in synaptic transmission and long-term memory. Nature 390:281-286.

Brandeis R, Brandys Y, Yehuda S (1989) The use of the Morris Water Maze in the study of memory and learning. Int J Neurosci 48:29-69.

Chen C, Kano M, Abeliovich A, Chen L, Bao S, Kim JJ, Hashimoto K, Thompson RF, Tonegawa S (1995) Impaired motor coordination correlates with persistent multiple climbing fiber innervation in PKC gamma mutant mice. Cell 83:1233-1242.

Cho KO, Hunt CA, Kennedy MB (1992) The rat brain postsynaptic density fraction contains a homolog of the Drosophila discs-large tumor suppressor protein. Neuron 9:929-942.

Cho YH, Friedman E, Silva AJ (1999) Ibotenate lesions of the hippocampus impair spatial learning but not contextual fear conditioning in mice. Behav Brain Res 98:77-87.

Costa RM, Yang T, Huynh DP, Pulst SM, Viskochil DH, Silva AJ, Brannan CI (2001) Learning deficits, but normal development and tumor predisposition, in mice lacking exon 23a of Nf1. Nat Genet 27:399-405.

Crawley JN (1985) Exploratory behavior models of anxiety in mice. Neurosci Biobehav Rev 9:37-44.

Ebinu JO, Bottorff DA, Chan EY, Stang SL, Dunn RJ, Stone JC (1998) RasGRP, a Ras guanyl nucleotide-releasing protein with calcium- and diacylglycerol-binding motifs. Science 280:1082-1086.

English JD, Sweatt JD (1996) Activation of p42 mitogen-activated protein kinase in hippocampal long term potentiation. J Biol Chem 271:24329-24332.

English JD, Sweatt JD (1997) A requirement for the mitogen-activated protein kinase cascade in hippocampal long term potentiation. J Biol Chem 272:19103-19106.

Fam NP, Fan WT, Wang Z, Zhang LJ, Chen H, Moran MF (1997) Cloning and characterization of Ras-GRF2, a novel guanine nucleotide exchange factor for Ras. Mol Cell Biol 17:1396-1406.

Ferguson GD, Anagnostaras SG, Silva AJ, Herschman HR (2000) Deficits in memory and motor performance in synaptotagmin IV mutant mice. Proc Natl Acad Sci USA 97:5598-5603.

Fuchs RA, Weber SM, Rice HJ, Neisewander JL (2002) Effects of excitotoxic lesions of the basolateral amygdala on cocaine-seeking behavior and cocaine conditioned place preference in rats. Brain Res 929:15-25.

Giese KP, Friedman E, Telliez JB, Fedorov NB, Wines M, Feig LA, Silva AJ (2001) Hippocampus-dependent learning and memory is impaired in mice lacking the Ras-guanine-nucleotide releasing factor 1 (Ras-GRF1). Neuropharmacology 41:791-800.

Han L, Wong D, Dhaka A, Afar D, White M, Xie W, Herschman H, Witte O, Colicelli J (1997) Protein binding and signaling properties of RIN1 suggest a unique effector function. Proc Natl Acad Sci USA 94:4954-4959.

Hariri AR, Mattay VS, Tessitore A, Kolachana B, Fera F, Goldman D, Egan MF, Weinberger DR (2002) Serotonin transporter genetic variation and the response of the human amygdala. Science 297:400-403.

Herrmann C, Horn G, Spaargaren M, Wittinghofer A (1996) Differential interaction of the ras family GTP-binding proteins H-Ras, Rap1A, and $\mathrm{R}$-Ras with the putative effector molecules Raf kinase and Ral-guanine nucleotide exchange factor. J Biol Chem 271:6794-6800.

Irvin DK, Zurcher SD, Nguyen T, Weinmaster G, Kornblum HI (2001) Expression patterns of Notch1, Notch2, and Notch3 suggest multiple functional roles for the Notch-DSL signaling system during brain development. J Comp Neurol 436:167-181.

Kantak KM, Black Y, Valencia E, Green-Jordan K, Eichenbaum HB (2002) Dissociable effects of lidocaine inactivation of the rostral and caudal basolateral amygdala on the maintenance and reinstatement of cocaineseeking behavior in rats. J Neurosci 22:1126-1136.

Kennedy MB (2000) Signal-processing machines at the postsynaptic density. Science 290:750-754.

Koleske AJ, Gifford AM, Scott ML, Nee M, Bronson RT, Miczek KA, Baltimore D (1998) Essential roles for the Abl and Arg tyrosine kinases in neurulation. Neuron 21:1259-1272.

Komiyama NH, Watabe AM, Carlisle HJ, Porter K, Charlesworth P, Monti J, Strathdee DJC, O'Carroll CM, Martin SJ, Morris RGM, O'Dell TJ, Grant SG (2002) SynGAP regulates ERK/MAPK signaling, synaptic plasticity and learning in the complex with PSD-95 and NMDA receptor. J Neurosci 22:9721-9732.

Kruzich PJ, See RE (2001) Differential contributions of the basolateral and 
central amygdala in the acquisition and expression of conditioned relapse to cocaine-seeking behavior. J Neurosci 21:RC155(1-5).

LeDoux JE (2000) Emotion circuits in the brain. Annu Rev Neurosci 23:155-184.

Lin CH, Yeh SH, Lu KT, Leu TH, Chang WC, Gean PW (2001) A role for the PI-3 kinase signaling pathway in fear conditioning and synaptic plasticity in the amygdala. Neuron 31:841-851.

Mazzucchelli C, Vantaggiato C, Ciamei A, Fasano S, Pakhotin P, Krezel W, Welzl H, Wolfer DP, Pages G, Valverde O, Marowsky A, Porrazzo A, Orban PC, Maldonado R, Ehrengruber MU, Cestari V, Lipp HP, Chapman PF, Pouyssegur J, Brambilla R (2002) Knockout of ERK1 MAP kinase enhances synaptic plasticity in the striatum and facilitates striatalmediated learning and memory. Neuron 34:807-820.

Morris RG, Garrud P, Rawlins JN, O'Keefe J (1982) Place navigation impaired in rats with hippocampal lesions. Nature 297:681-683.

Ohno M, Frankland PW, Chen AP, Costa RM, Silva AJ (2001) Inducible, pharmacogenetic approaches to the study of learning and memory. Nat Neurosci 4:1238-1243.

Ozonoff S (1999) Cognitive impairment in neurofibromatosis type 1. Am J Med Genet 89:45-52.

Pham N, Cheglakov I, Koch CA, de Hoog CL, Moran MF, Rotin D (2000) The guanine nucleotide exchange factor CNrasGEF activates ras in response to cAMP and cGMP. Curr Biol 10:555-558.

Philip N, Acevedo SF, Skoulakis EM (2001) Conditional rescue of olfactory

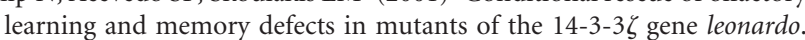
J Neurosci 21:8417-8425.

Rammes G, Steckler T, Kresse A, Schutz G, Zieglgansberger W, Lutz B (2000) Synaptic plasticity in the basolateral amygdala in transgenic mice expressing dominant-negative cAMP response element-binding protein (CREB) in forebrain. Eur J Neurosci 12:2534-2546.

Schafe GE, Atkins CM, Swank MW, Bauer EP, Sweatt JD, LeDoux JE (2000)
Activation of ERK/MAP kinase in the amygdala is required for memory consolidation of pavlovian fear conditioning. J Neurosci 20:8177-8187.

Schauz C, Koch M (2000) Blockade of NMDA receptors in the amygdala prevents latent inhibition of fear-conditioning. Learn Mem 7:393-399.

Shou C, Farnsworth CL, Neel BG, Feig LA (1992) Molecular cloning of cDNAs encoding a guanine-nucleotide-releasing factor for Ras p21. Nature 358:351-354.

Silva AJ, Frankland PW, Marowitz Z, Friedman E, Lazlo G, Cioffi D, Jacks T, Bourtchuladze R (1997) A mouse model for the learning and memory deficits associated with neurofibromatosis type I. Nat Genet 15:281-284.

Tall GG, Barbieri MA, Stahl PD, Horazdovsky BF (2001) Ras-activated endocytosis is mediated by the Rab5 guanine nucleotide exchange activity of RIN1. Dev Cell 1:73-82.

Thomas MJ, Moody TD, Makhinson M, O’Dell TJ (1996) Activitydependent beta-adrenergic modulation of low frequency stimulation induced LTP in the hippocampal CA1 region. Neuron 17:475-482.

Wang Y, Miller AL, Mooseker MS, Koleske AJ (2001) The Abl-related gene (Arg) nonreceptor tyrosine kinase uses two F-actin-binding domains to bundle F-actin. Proc Natl Acad Sci USA 98:14865-14870.

Wang Y, Waldron RT, Dhaka A, Patel A, Riley MM, Rozengurt E, Colicelli J (2002) The RAS effector RIN1 directly competes with RAF and is regulated by 14-3-3 proteins. Mol Cell Biol 22:916-926.

Weeber EJ, Sweatt JD (2002) Molecular neurobiology of human cognition. Neuron 33:845-848.

Wu GY, Deisseroth K, Tsien RW (2001) Spaced stimuli stabilize MAPK pathway activation and its effects on dendritic morphology. Nat Neurosci 4:151-158.

Yamamoto T, Shimura T, Sako N, Yasoshima Y, Sakai N (1994) Neural substrates for conditioned taste aversion in the rat. Behav Brain Res 65: 123-137. 